\title{
Sufism Study in Communication Perspective
}

\author{
Muttaqien ${ }^{1}$, T. Faizin ${ }^{1}$, Saidaturrahmah ${ }^{1}$, Muhibuddin $^{1}$, Muhammad Khalidin $^{2}$, Rossa \\ $\underline{\text { Alfira }}^{2}$ \\ ${ }^{1}$ Lecturer of Al-Aziziyah Institute of Islamic Studies (IAI) Samalanga Bireun Aceh, Indonesia \\ ${ }^{2}$ Student of Al-Aziziyah Institute of Islamic Studies (IAI) Samalanga Bireun Aceh, Indonesia \\ Email: aqienmy@gmail.com
}

\begin{abstract}
:
Sufism is one of the fields of Islamic studies that focus on cleansing the spiritual aspects of humans, which in turn leads to noble morals. Through this study of Sufism one can find out about ways to do self-cleaning and practice correctly. From this knowledge it is hoped that he will appear as someone who is good at controlling himself when he interacts with others, or when carrying out activities that require honesty, sincerity, responsibility, trust and others. If viewed from the perspective of humans as limited beings, Sufism can be defined as an effort to purify self by way of distancing the influence of world life will focus attention only on Allah. Sufism comes from the Qur' an and Sunnah although in its development it was influenced by foreign elements. Sufism has developed since the end of the second century Hijri, although in the first century the hijri had been seen in the ascetic life form (zuhud) practiced by the Prophet and the ma'rifah sahabatuan. There are several approaches in Sufism study, thematic approach, figure study approach and combination approach. The main figures and works in the study of Sufism include Imam Al-Ghazali with his momental work Ihya 'Ulum al-Din, Ibn Arabi with his work Al-Futuhat al-Makkiyah and Fushush al-Hikam and others mentioned earlier. The latest development of Sufism stems from the thought of Fazlur Rahman with the concept of neo sufism. In Indonesia, Hamka has featured the term modern Sufism in his book "Modern Sufism". If Al-Ghazali requires uzlah in the exploration of the quality of nature, then Hamka actually wants a true truth seeker to remain active in various aspects of people's lives.

Keywords :

Al-Quran; sufism; communication; sufi order; tariqat
\end{abstract}

\section{Introduction}

Islam as a universal religion, besides requiring physical cleanliness also requires inner cleanliness, because the actual evaluation in Islam is given to its inner aspects. This can be seen in one of the requirements for the acceptance of acts ofworship, which must be accompanied by intention.

Sufism is one of the fields of Islamic studies that focus on cleansing the spiritual aspects of humans, which in turn leads to noble morals. Through this study of Sufism one can find out about ways to do self-cleaning and practice correctly. From this knowledge it is hoped that he will appear as someone who is good at controlling himself when he interacts with others, or when carrying out activities that require honesty, sincerity, responsibility, trust and others. From such an atmosphere, Sufism is expected to overcome various moral deviations such as manipulation, corruption, collusion, abuse of power and opportunity, oppression and so on.

Seeing the importance role of Sufism in the survival of the whole person, it is not surprising that Sufism is familiar with the life of the Islamic community after the community fostered the faith and worship through the science of monotheism and science of jurisprudence. In this regard, researchers have emerged who concentrate their studies on the problem of Sufism, the results of which have been presented in various literatures. 
This simple paper will explain some key terms such as Sufism, Sufi and Tariqat, sources and developments of Sufism thinking, variations of Sufism practices, main approaches in Sufism studies, main characters and works in Sufism studies, and the latest development of Sufism studies.

\section{Review of Literature}

\subsection{Sufism}

Many definitions of Sufism are formulated by Sufism scholars, but do not include the understanding of Sufism as a whole. This is because none of the scholars of Sufism gives a definition of science as philosophers. Sufism experts only describe about a state of being experienced in the life of Sufism at a certain time. Besides that, different ways of looking at Sufism activities also give birth to different definitions.

In terms of language there are a number of words or terms that people associate with Sufism. Harun Nasution, for example, mentioned five terms related to Sufism, namely al Suffah (abl al-suffah), that is, one who moved with the Prophet from Mecca to Medina, sufi which is the line that is found in carrying out congregational prayers, the Sufi that is clean and holy, sophos (Greek: wisdom), and sufi (rough wool).

In terms of Linguistics (linguistic) it can immediately be understood that Sufism is a mental attitude that always maintains the sanctity of self, worship, simple life, willing to sacrifice for good and always be wise. Such attitude of the soul is essentially noble character.

If we pay close attention, it seems that the five terms have themes about praiseworthy qualities and circumstances, simplicity and closeness to God. Thus, in terms of the habits of Sufism describe conditions that are always oriented to the purity of the soul, prioritizing the truth and willing to sacrifice for the nobler goals on the side of God.

In terms of terms, Sufism can be defined from three points of view. First, the point of view of humans as limited beings, second, the point of view of humans as beings who must struggle, and third, the point of view of humans as godly beings.

If viewed from the perspective of humans as limited beings, Sufism can be defined as an effort to purify self by way of distancing the influence of world life will focus only on God. Furthermore, if the viewpoint used is the view that humans as creatures who must fight, then Sufism can be defined as an effort to beautify themselves with morals that is based on religious teachings in order to draw closer to God. And if the viewpoint used is human beings as godly beings, then Sufism can be defined as a state of fitrab (a feeling of trust in God) that can direct the soul to always be focused on activities that can connect humans with God.

If the three definitions of Sufism mentioned above are related to one another, then it soon appears that Sufism is essentially an effort to train the soul with various activities that can free itself from the influence of world life, so that it is reflected in the noble character and close to Allah SWT. In other words Sufism is a field of activity that deals with spiritual mental formation to be always close to God. This is the essence or essence of Sufism. 


\subsection{Sufi}

The word Sufi or literal is interpreted as a person who always practices the teachings of Sufism in everyday life. In other words, Sufi means one who has purified his heart by remembering Allah (zikrullah), taking the path back to Allah and arriving at ultimate knowledge (ma'rifah).

One people said, that they named shufiyah because they were in the front row (shaf) in the side of Allah 'Azza wa Jalla with the height of their aspirations to Him and their sincerity to meet Him and the determination (determination) of their hearts on the his side.

Some attributed the word to the word ash-shufu which means coarse wool or wool. This is because Sufis specialize themselves in clothing that comes from sheep's fur. The only wool cloth worn by the Sufis was coarse wool, not fine wool, which is used today. Wearing wool at the time was a symbol of simplicity and poverty. His opponent is wearing silk, by people who live in luxury among the government. The Sufis as a group, who live modestly and in a state of poverty, but have a pure and noble heart, avoid the use of silk and instead use coarse wool.

However, as emphasized by Ibn Khaldun that a person cannot simply be called a Sufi simply because he wears clothes made of coarse wool. These clothes depict that they are very simple people who do not present themselves with clothes that are nice, smooth and expensive. This can be seen from the word Sufi itself which means rough woolen cloth. This illustrates their inclination towards worldly life.

\subsection{Tariqat}

In lughat (language), tariqat is Arabic that has been in Indonesian which means "road, method, line, position, belief and religion". In Islamic Encyclopedia, Tariqat or tarekat means: road, way (al kaifiyah), method, system (al uslub), school, school, flow, direction (al school), and tall date palm tree (and never at tawilab), pillar of shelter, the umbrella stick ('amud al mizallah), the noble, the foremost of the clan (syarif al qaum). Louis Ma'luf defines it by way, state, flow in a line on something. This word with different lafadz is used in da'wah (turku or dukwah turukud) with the same meaning that is way or manhaj (method).

According to the term (Sufis) Tariqat means the journey of a salik. / follower of the tarekat towards God by purifying oneself, or a journey that must be taken by someone to be as close as possible to God. Al Jurjani said that the Tariqat is a certain way or behavior for people worshiping Allah starting the stage towards a higher level called maqamat.

Thus what is meant by Tariqat in this case is a certain way or path chosen by the Sufis to purify themselves in an effort to draw closer to Allah. In its development this method became a method arranged in such a way by a Sufi leader of the Tariqat, so that it became a certain characteristic that distinguishes it from other Tariqat. Furthermore, the tarekat also develops into a system or institution which involves scholarship, practice and the formation of an attitude which has a leader and a certain place responsible for all activities in the Tariqat institution. Therefore, every Tariqat can be different from other Tariqat, especially its practice method. But it needs to be explained that all Tariqat have the same goal which is to purify the soul to be close to Allah.

Tariqat as a way or way is not just how to be done in order to be better and easier to be close to God, but more than that the Tariqat is also a group, even an organization. As an organization each Tariqat has its own name that is different from the others, has leaders, members, specific residences, certain teachings and how to implement them, even Tariqat as an organization or usually called Sufism flow pretty much develops with different names and teachings- different, 
such as the Naqsabandiyah order, the Samadiyah order, the Rifa'iyah order, the Qadariyah order, the Khalidiyah order and others.

\section{Discussion}

Along with the emergence of sharp criticisms of Sufism that causes tension in the world of Islamic thought, it seems that various arguments have arisen about, is Sufism really Islamic science or is it merely the Islamization of non-Islamic elements? The controversy began since the appearance of philosophical Sufism and was further sharpened later by the inclusion of Orientals opinion, which generalization says, that Sufism is sourced from outside of Islam. Those who say Sufism comes from outside Islam, whether from Persia, Hinduism, Christianity, Greek philosophy and or from other sources, basing their opinions only because of the mere similarity of typology. Such opinions appear to be dishonest and not objective. Because, there is no scientific paradigm that ensures that all the same or similar is due to mutual influence or because of plagiarism. However, throughout the author's research, it can be ascertained that the initial source and principle of Sufism is Islam, so that it is classified as one aspect of distinctive Islamic culture.

The basics of Sufism have existed since the arrival of Islam; this can be known from the life of the Prophet Muhammad. His way of life was then emulated and passed on by friends. During the Makkiyah period the spiritual awareness of the Prophet Muhammad was based on clear and certain mystical experiences.

Alquran is a book in which found a number of verses that speak or at least relate to the things mentioned above. In the Koran found the command to worship and dhikr, including: (Q.S. Al-Anbiya: 25)

And we sent not before you any messenger except that we revealed to him that, "There is no deity except me, so worship Me."

(Q.S. Al-Anfal : 45)

And say (name) Allah as much as possible so that you are lucky".

About how you should see world life, the Koran among them emphasizes: $O$ mankind, indeed the promise of Allah is truth, so let not the worldly life delude you and be not deceived about Allah by the Deceiver. (Q.S Fathir: 5)

The development of Sufism in Islam has undergone several phases, namely:

First, the asceticism (zubud) phase which grew in the first and second centuries of hijriyah. In this phase there are individuals from Muslim circles who focus more on worship. They run the ascetic conception in life, which is not concerned with food, clothing, and shelter. They are more charitable for matters relating to the afterlife. Very popular figures from among them were Hasan al-Basri (w.110H) and Rabi'ah al-Adawiyah (d. $185 \mathrm{H}$ ).

In the third century Hijriyah, Sufism experts tried to investigate the teachings of Sufism that developed at that time, so they divided it into three parts, namely:

a. Sufism that contains psychology, namely Sufism that contains a complete method of treatment of the soul, which concentrates human psychology to his Khaliq so that mental tension due to worldly influences can be overcome properly.

b. Sufism with its core of morality, which contains instructions on how to do well. 
c. Sufism which contains metaphysics, which contains teachings that describe the Divine oneness which is the only one that exists in an absolute sense.

At the end of the third century Hijriyah, new considerations began to emerge in the history of Sufism, which was marked by the emergence of educational and teaching institutions which included Sufism teaching activities and spiritual exercises. So from here comes the term Tariqat.

In the fourth century Hijriyah, Sufism advanced more rapidly when compared to the third century. The scholars developed the teachings of Sufism each. So that the city of Baghdad as the only city that is famous as the center of the most Sufism activities before that time, rivaled by other big cities. Scholars who developed the teachings of Sufism include:

1. Musa al-Ansary, taught Sufism in Khurasan (Iran). Died $320 \mathrm{H}$.

2. Abu Hamid bin Muhammad al-Rubazy, taught in one city in Egypt. Died in $322 \mathrm{H}$.

3. Abu Ali Muhammad bin Abdil Wahhab al-Saqafy, taught at Naisabur. Died in $328 \mathrm{H}$.

4. In the fifth century Hijri appeared the Imam al-Ghazali who fully only accepted Sufism

Based on the Qur'an and Sunnah and aimed at asceticism, simple living, soul straightening, and moral guidance. Knowledge of Sufism is studied in depth. On the other hand, he launched a sharp criticism of philosophers. The way he traveled to resolve the dispute was by affirming that ecstatic speech came from wisdom that was in a sacred or amazed condition. Because in reality, said al-Ghazali, after they realized they also recognized, that unity with God is not an intrinsic unity, but symbolic unity.

In the sixth century Hijriyah emerged a group of Sufism figures who combined their Sufism with philosophy, with their theories which were half-hearted. It is called pure Sufism, not pure philosophy. They include al-Suhrawardi al-Maqtul (d. 549 AH) Muhyiddin Ibn al-abiArabi (d. 638 AH), Umar Ibnu al-Farid (d. 632 AH).

With the emergence of Sufis who were also philosophers, people began to distinguish them from Sufism which was originally developed, namely Sufism which is identical to Sunni Sufism. Thus, the flow of Sufism is divided into two, Sunni Sufism and philosophical Sufism.

In the seventh century recorded in history, which lowered the passion of the Islamic community to study Sufism. This is due to:

1. Increasingly the onslaught of shari'ab scholars fighting Sufism

2. The determination of the authorities (government) at that time to eliminate the teachings of Sufism in the Islamic world, because this activity is considered as a source of division among Muslims.

Sufism in the last days (more or less than the eighth century bijriyah until now) suffered a setback. With the end of the seventh century and the coming of the eighth century, no new developments or thoughts were heard in Sufism. Although many Sufi authors expressed thoughts such as al-Kasani (d. $739 \mathrm{H}$ ), he no longer issued a new opinion. Likewise with the Sufi figure Abdul Karim al-Jaili the author of the book "Insan Kamil". This book contains nothing more than explaining and beautifying the ideas of Ibn 'Arabi and Jalaluddin Rumi.

Sufis have different ways of implementing life and the teachings of Sufism. Experiences in getting closer to God make the practice of Sufism more varied. Because seven of the Sufis are as 
close as possible to God so that unity is achieved, then the way to achieve that goal is long and contains maqamat. Maqamat commonly mentioned include repentance, zubud, patience, tawakal and riza. On top of that there is al-mahabbah (love), al-ma'rifah (knowledge), al-fana and al-baqa (destruction and continuation and itihad (unity).

Rabi'ah al-Adawiyah (d. $185 \mathrm{H}$ ) was a man who had a lot of love for God. He said, "I serve God not because I am afraid of going to hell, nor do I want to go to heaven, but because of my love for Him. Love for God fills his soul so much that there is no room for love for others.

Rabi'ah al-Adawiyah classifies Divine love into two types. First, the love that arises from the favors and goodness given by God. Second, love that is not driven by sensual pleasure, but is driven by a substance that is loved which is the opening of the curtain so that God is real to him.

Faham al-ma'rifah was pioneered by $\mathrm{Zu}$ al-Nun al-Misri (d. $214 \mathrm{H})$. According to him, $m a^{\prime}$ rifah is different for each person. The ma'rifah about the oneness of Allah that lay people have is based on the imitation; the main ma'rifah is sourced from the proposition. Whereas ma'rifah for Sufi experts or guardians of Allah is sourced from kasyf and musyaadah. According to Zu al-Nun al-Misri, the true ma'rifah to Allah brings His light in the heart until it is clear and clear, making people always draw close to God so that they become mortal in His oneness. In such circumstances, people speak with the knowledge that He has given, see with His vision, do with His actions. So ma'rifah is something that is subtle and rises from the deepest heart, given by God so that the veil is open and the solution is clear.

There are several approaches taken in the study of Sufism, namely:

\section{Thematic Approach}

Thematic approach means, the approach that tries to present the teachings of Sufism in accordance with certain themes. Among them is a description of the function of Sufism, the levels of spirituality in Sufism and the development of Sufism. In it stated that Sufism is a means to establish a relationship with God in an effort to achieve human wholeness.

This approach was carried out by Sayyed Husein Nasr when conducting research in the field of Sufism with the title: Sufism Then and now, which was translated by Abdul Hadi.

\section{Figure Study Approach}

When Emperor Azhari Noor (a lecturer at Usuludin IAIN Syariff Hidayatullah Jakarta) conducted a research in the field of Sufism with the title: Ibn 'Arabi: wabdat al-wujud in the debate, he used a character study approach. This research is quite interesting, because in terms of the ideology it brings, namely wahdat al-wujud has caused controversy among the scholars, because the ideology is valued to bring the reincarnation or all-rounded understanding of God, namely God incarnated in various creations, so that it can disrupt the existence of God's substance. Wabdat al-wnjud which means the unity of existence is a continuation of bulul ideology.

This misunderstanding of wahdat al-wujud arises from the understanding that Allah wants to see himself, so he made it natural. Then this nature is a mirror for God. When he sees himself, he looks to nature, to the things that are in nature, because in each of these objects there is the nature of God. From here arises the understanding of unity. There is much in nature, but actually it is one. Not like someone who sees himself in a number of mirrors placed around him. 


\section{Combination Approach}

In his book entitled Tidal Flow of Sufism, Arberry tries to use a combination approach, a thematic approach with a character approach. With this approach he tried to bring forth the word of God, the life of the Prophet, the rabids, the Sufis, the theorists of Sufism. The practice of Sufism, Sufi orders and the collapse of Sufism. From the contents of the research it appears that Alberry uses historical analysis, and does not carry out the process of actualizing values or transforming these teachings into the broader meaning of modern life.

\section{Phenomenology Approach}

According to Charles J Adams among many fields of study in Islamic studies, Sufism is an area of interest in recent years. The study of Islamic traditions cannot be separated from the study of mysticism which might also be an aspect that emerged in the early days of Islam even in the period of prophet hood. Adams pointed out several scholars interested in studying Sufism, including Annemarie Schimmel, with her book Mystical Dimensions of Islam. The most important thing from Adam's opinion is to study Sufism can be approached with a phenomenological approach.

The phenomenological approach is an approach that pays more attention to subjective experiences, individuals because of that behavior is strongly influenced by an individual's view of himself and his world. The concept of himself, his self-esteem and all matters concerning his awareness or actualization. This means seeing a person's behavior is always associated with phenomena about themselves.

Indeed Sufism until the last decade has not yet been counted as a closed field for academic studies. So since the end of the nineteenth century, Sufism has become a study of various scientific studies that are not limited to Muslim researchers, but more than that non-Muslim researchers also Orient lists study it, these are famous names in Islamic Sufism literature such as Annemerie Schimel, Tholouck, Arberry, Norman Daniel, Nicholson, Goldziher and others.

Islamic Sufism throughout history has attacked the opinions of thinkers from easterners and westerners, as well as attracting them with all their strengths so that they feel amazed at what depends on Islamic Sufism itself, both in terms of value and authenticity. Although the existence of Sufism in Islam has increasingly become a part of scientific studies, especially in recent decades, there is a clear opinion on various issues. This is influenced by negative factors resulting from various scientific studies, not come Sufism or Sufi itself.

The latest development of Sufism stems from the thought of Fazlur Rahman with the concept of neo sufism. In Indonesia, Hamka has featured the term modern Sufism in his book "Modern Sufism". If Al-Ghazali requires uzlah in the exploration of the quality of nature, then Hamka actually wants a true truth seeker to remain active in various aspects of people's lives.

According to Fazhur Rahman as the initiator of the term neo Sufism, neo sufism is "reformed Sufism", a renewed Sufism. If in the era of the glory of Sufism before, the most dominant aspect was the ecstatic-metaphysical or mystical-philosophical nature, and then in this new Sufism it was replaced or reformed with orthodox Islamic principles. Neo-Sufism shifts the focus of observation to the socio-moral reconstruction of Muslim societies, whereas earlier Sufism seemed to be more individual and "almost" not involved in social matters. 


\section{Conclusion}

Sufism as one of the fields of Islamic studies, is very important for the survival of the whole person, because Sufism directs people to purification of them from the influence of the world, adorn themselves with good morals to get closer to God, which in turn reaches the knowledge.

Sufism comes from the Qur'an and Sunnah although in its development it was influenced by foreign elements. Sufism has developed since the end of the second century bijriyah, although in the first century the hijriyah had been seen in the ascetic life form (zubud) practiced by the Prophet and the ma'rifah sahabatuan.

There are several approaches in Sufism study, thematic approach, figure study approach and combination approach. The main figures and works in the study of Sufism include Imam AlGhazali with his momental work Ihya 'Ulum al-Din, Ibn Arabi with his work Al-Futuhat alMakkiyah and Fushush al-Hikam and others mentioned earlier.

The latest development of Sufism stems from the thought of Fazlur Rahman with the concept of neo sufism. In Indonesia, Hamka has featured the term modern Sufism in his book "Modern Sufism". If Al-Ghazali requires uzlah in the exploration of the quality of nature, then Hamka actually wants a true truth seeker to remain active in various aspects of people's lives.

\section{References}

Islam Ditinjau Dari Beberapa Aspeknya. Jakarta: UI Press, 1986.

. Memahami ajaran tasawwuf. Surabaya: Bintang Usaha Jaya, 2001.

Anwar, Rosihan. Ilmu Tasawnf. Bandung: Pustaka Setia, 2000.

Basuni, Ibrahim. Nas'ah al-Tasawuf al-Islam. Makkah: Dar al-Ma'rifat, 1119.

Hamka, Tasawuf Perkembangan dan Pemurniannya. Jakarta: Pustaka Panjimas, 1993.

Hoeve, Van. Ensiklopedia Islam Jakarta. Ikhtiar Baru, 1993.

Jurjani. Ta'rifat, Albabil Halaby. Mesir: tp, 1978.

Khaldun, Ibn. Al-Muqaddimah. Beirut: Dar al-Fikri, t.t.

Ma'luf, Louis. Al Munjid fil Luagh. Bairut: Darul Masyriq, 1973.

Mahyuddin, Kuliah Akblah Tasawuf. Jakarta: Kalam Mulia, 2001.

Mansur, Laily. Ajaran dan Teladan Para Sufi. Jakarta: Sri Gunting, 1996.

Muttaqien, (2018). Ethics Relevance of Interpersonal Communication in Ibya Ulun Al-Din with Islamic Communication. Medan: Bircu Publisher.

Mz, Labib. Kisah Perjalanan Tokoh Sufi Terkemuka. Surabaya: Tiga Dua, 2000.

Nasrullah, M.S. Kunci Memasuki Dunia Tasawuf. Bandung: Mizan, 1996.

Nasution, Harun. Falsafat dan Mistisisme Dalam Islam, Jakarta: Bulan Bintang, 1973.

Nata, Abuddin. Metodologi Studi Islam. Jakarta: PT. Raja Grafindo Persada, 2000.

Said, Fuad. Hakikat Naqsabandiyah. Jakarta: Alhusna Zikra, 1993.

Saiful Bahri, (2019) Syarkawi Syarkawi, Mursal Mursal, Fizazuawil Fizazuawil, Maimun Maimun, Trust Giving Transactions on Mu'amalah Al-Wadi'ah. Medan: Bircu Publisher.

Saiful Bahri, (2018). Hadiths About Communication Ethics (Study of Hadiths about Responsibility and Maintaining Information Accuracy). Medan: Bircu Publisher.

Siregar, Rivay. Tasawuf dari Sufisme Klasik ke Neo Sufisme. Jakarta: Raja Grafindo Persada, 2000.

Solihin. Sejarah dan Pemikiran Tasawnf di Indonesia. Bandung, Pustaka Setia 2001. 